\title{
PENGEMBANGAN BAHAN AJAR MATA KULIAH BERBICARA DENGAN METODE STUDENT FACILITATOR AND EXPLAINING DI UNIVERSITAS PERADABAN
}

\author{
Cintya Nurika Irma ${ }^{1}$, Ririn Setyorini ${ }^{2}$ \\ Cintya_nurikairma@yahoo.co.id, Ririnsetyorini91@gmail.com \\ Program Studi Pendidikan Bahasa Indonesia, Fakultas Keguruan dan Ilmu \\ Pendidikan \\ Universitas Peradaban, Bumiayu
}

\begin{abstract}
Abstrak
Penelitian ini dilakukan dengan tujuan mendeskripsikan dan menjelaskan: (1) kebutuhan mahasiswa Universitas Peradaban mengenai bahan ajar Mata Kuliah Berbicara yang diperlukan, (2) mengembangkan dan menguji keefektifan bahan ajar Mata Kuliah Berbicara dengan metode student facilitator and explaining di Universitas Peradaban, dan (3) tanggapan mahasiswa dan dosen lain terhadap kelayakan bahan ajar Mata Kuliah Berbicara dengan metode Student Facilitator and Explaining di Universitas Peradaban. Selanjutnya, metode penelitian pengembangan digunakan dalam penelitian ini untuk menghasilkan bahan ajar dengan tiga tahapan, yaitu: tahap studi pendahuluan, tahap studi pengembangan, tahap evaluasi. Hasil penelitian diketahui (1) kebutuhan bahan ajar menurut dosen dan mahasiswa perlu memperhatikan a) pemilihan bahasa, b) topik pembelajaran disesuaikan dengan permasalahan yang dekat dengan mahasiswa, c) terdapat latihan dan tugas dalam tiap materi yang mudah dipahami, dan d) bahan ajar siap digunakan dalam kondisi universitas yang minimal, (2) mengembangkan prototype menjadi bahan ajar berbicara di Universitas Peradaban, dan (3) hajil uji keefektifan menunjukkan bahan ajar berbicara dengan metode student facilitator and explaining dinyatakan baik.
\end{abstract}

Kata Kunci: Pengembangan Bahan Ajar, Berbicara, Metode Student Facilitator and Explaining

\begin{abstract}
Abstrack
This research was conducted with the aim of describing and explaining: (1) the needs of Peradaban University students regarding the required teaching materials for Speaking Courses, (2) developing and testing the effectiveness of course teaching materials Speaking with the student facilitator method and explaining at the Peradaban University, and (3) the responses of students and other lecturers to the feasibility of teaching materials for the course Speaking with the Student Facilitator method and Explaining at the Peradaban University. Furthermore, the development research method is used in this study to produce teaching materials with three stages, namely: preliminary study stage, development study stage, evaluation phase. The results of the study are known (1) the need for teaching materials according to lecturers and students need to pay attention to a) language selection, b) learning topics tailored to problems close to students, $c$ ) there are exercises and assignments in each material that is easy to understand, and d) teaching materials are ready to be used in the university's minimal conditions, (2) developing prototypes into teaching materials at the Peradaban University, and (3) the test of effectiveness shows teaching materials to speak with student facilitator and explaining methods declared good.
\end{abstract}

Keywords: Development of Teaching Materials, Speaking, Student Facilitator and Explaining Methods

\section{PENDAHULUAN}

Mahasiswa dituntut untuk dapat merealisasikan kemahirannya dalam berbicara. Tentu keberhasilan mengidentifikasi konteks dalam berbicara menjadi faktor ketercapaian maksud tuturan yang diharapkan. Ketercapaian dalam berbicara tidak boleh mengabaikan kesantunan verba dan nonverbal. Kesantunan verba dapat dicermati melalui penerapan faktor-faktor linguistik, diksi, rangkaian kalimat, kecepatan berbicara, jeda, dan intonasi. Selanjutnya, kesantunan nonverbal terikat pada jarak berbicara antara penutur dengan mitra tutur, ekspresi, dan gerakan tubuh. Permasalahan tersebut masih sering dialami dalam diri penutur tetapi permasalahan tersebut dapat teratasi melalui pemahaman dan proses pembelajaran secara berkelanjutan sehingga terhindar dari 
bentuk penyimpangan dan kegagalan dalam bertutur.

Kendala terkait berbicara diatasi melalui Program Studi Pendidikan Bahasa dan Sastra Indonesia (PBSI) FKIP Universitas Peradaban dengan adanya Mata Kuliah Berbicara 1 yang dilaksanakan pada semester 1 dan Mata Kuliah Berbicara 2 pada semester 3 guna membekali mahasiswa dalam pemahaman dan peningkatan kemampuan berbicara. Berdasarkan hasil wawancara dan observasi dengan dosen Berbicara 1 disimpulkan bahwa diidentifikasi terdapat delapan permasalahan penyebab kurang optimalnya pembelajaran berbicara yang telah terlaksana di PBSI. Pertama, rendahnya minat mahasiswa pada Mata Kuliah Berbicara. Kedua, mahasiswa masih mengalami kesulitan dalam menentukan diksi. Ketiga, mahasiswa belum terbiasa merealisasikan kesantunan nonverbal saat berkomunikasi. Keempat, mahasiswa hanya diarahkan pada penampilan individu.

Kelima, mahasiswa belum memahami cara mengatasi rasa gugup, olah suara, dan penunjang keberhasilan berbicara. Keenam, belum tersedianya buku ajar berbicara sebagai bahan tambahan pengetahuan mahasiswa. Ketujuh, mahasiswa belum maksimal diberikan pengalaman langsung berbicara di depan umum sehingga praktik hanya dilakukan di dalam kelas. Kedelapan, rendahnya rasa percaya diri mahasiswa saat berbicara di depan umum. Belum tersedianya buku ajar berbicara menjadi perhatian untuk dilakukan tindakan berikutnya dengan mewujudkan pengembangan bahan ajar berbicara yang disesuaikan dengan kebutuhan bagi mahasiswa, program studi, universitas, dan masyarakat. Selanjutnya, Departemen Pendidikan Nasional (2008: 145-162) memberikan cakupan bahan ajar meliputi (1) judul, (2) materi pembelajaran, (3) standar kompetensi, (4) kompetensi dasar, (5) indikator, (6) petunjuk belajar, (7) tujuan yang dicapai, (8) informasi pendukung, (9) latihan, (10) petunjuk kerja, dan (11) penilaian.

Penelitian Faizah (2013) berjudul "Pengembangan Bahan Ajar Mata Kuliah Berbicara Berbasis Cooperative Learning Think-PairShare (TPS) di Universitas Muhamamdiyah Purworejo" diketahui bahwa bahan ajar perlu memperhatikan konteks bahasa, tema mengikuti perkembangan zaman, tugas atau latihan yang mengarah pengembangan berbicara aktif, materi menarik, siap dipakai pada kondisi fasilitas universitas yang minimal. Senada dengan penelitian yang dilakukan oleh Faizah, perlu dilakukan strategi untuk meningkatkan minat mahasiswa dalam pembelajaran berbicara. Upaya mengatasi permasalahan tersebut dilakukan dengan menerapkan metode pembelajaran student facilitator and explaning yang menekankan pada teman sejawat sebagai pendamping dosen dalam menyukseskan proses pembelajaran bagi mahasiswa lainnya melalui perancangan yang terstruktur.

Selanjutnya, penerapan pembelajaran model student facilitator and explaning diarahkan pada langkah-langkah 1) pendidik memaparkan tujuan dan kompetensi yang akan dicapai dalam perkuliahan, 2) pendidik menjelaskan ruang lingkup materi 
yang diajarkan pada peserta didik, 3) pendidik membuat kelompok student facilitator lalu menyampaikan konsep pembelajaran yang akan dilakukan penjelasan kelompok tersebut pada teman sejawat yang akan dilakukan berikutnya, 4) pendidik mengamati proses perkuliahan dan menghampiri jika peserta didik mengalami kesulitan, 5) tiap kelompok menyampaikan hasil diskusinya dan kelompok lain menanggapinya, dan 6) pendidik melakukan evaluasi dari proses perkuliahan dan menyampaikan materi. Kelompok student facilitator dapat dipilih melalui hasil observasi dan hasil penilaian dengan kriteria memiliki tingkat pemahaman yang baik.

Terealisasinya bahan ajar dapat mendukung ketercapaian model student facilitator and explaning guna mencapai kompetensi yang diharapkan melalui bahan ajar utama dan bahan ajar pelengkap. Selanjutnya, tujuan penelitian ini adalah untuk mendeskripsikan dan menjelaskan: 1) kebutuhan mahasiswa Universitas Peradaban mengenai bahan ajar Mata Kuliah Berbicara yang diperlukan, 2) mengembangkan dan menguji keefektifan bahan ajar Mata Kuliah Berbicara dengan metode Student Facilitator and Explaining di Universitas Peradaban, dan 3) tanggapan mahasiswa dan dosen lain terhadap kelayakan bahan ajar Mata Kuliah Berbicara dengan metode Student Facilitator and Explaining di Universitas Peradaban.

\section{TEORI}

a) Kesantunan Verbal dan Nonverbal

Saat berbicara bukan hanya kepentingan pribadi saja tetapi kepentingan pendengar tidak boleh dihiraukan. Beberapa hal yang perlu diperhatikan dengan cermat saat komunikasi dan interaksi profesional berlangsung yaitu (a) hindari katakata khusus, bentuk-bentuk jargon, dan bahasa gaul pada saat berkomunikasi dan interaksi profesional, (b) batasi pemakaian istilah-istilah teknis yang hanya memang ada di dalam bidang-bidang tertentu, (c) berikan data statistik yang relevan bilamana memang diperlukan, khususnya untuk maksud-maksud formal, maksudmaksud yang membutuhkan komputasi atau hitungan, (d) gunakanlah akronim secara tepat dan benar, (e) hindarilah gaya bahasa, idiom, dan metafora disekeliling orang yang bahasanya tidak terlalu baik (Rahardi, 2007: 135).

Bagaimana dengan kesantunan nonverbal? Sebagian penutur sering mengabaikan hal tersebut disebabkan kurangnya pemahaman. Chaer (2010: 7) mengemukakan bahwa gerak-gerik fisik dalam etika bertutur berkenaan dua hal, yaitu kinesik dan proksimik. Kinesik meliputi ekspresi, gerak tubuh, vokal, dan lain sebagainya sedangkan proksimik terkait jarak antara penutur dengan mitra tutur. Selanjutnya, pada komunikasi nonverbal perlu diperhatikan penggunaan faktorfaktor linguistik, yaitu: (1) artikulasi yang tepat, (2) mengartikulasikan konsonan, (3) pitch, (4) kerasnya suara, (5) kecepatan (rate), dan (6) jeda. Selain faktor linguistik, pada komunikasi nonverbal juga perlu diperhatikan penggunaan suara dan gerak tubuh. 
b) Pembelajaran Berbicara di Perguruan Tinggi

Berbicara merupakan bagian dari keterampilan berbahasa. Kemampuan berbicara akan berhasil dengan merealisasikan keterampilan berbahasa menyimak, membaca, dan menulis. Oleh sebab itu, keempat aspek tersebut harus diberikan secara terus menerus dalam pembelajaran bahasa dan diberikan dengan proporsi yang seimbang. Perlunya pembelajaran berbicara secara berkelanjutan perlu menjadi perhatian meskipun kegiatan tersebut dilakukan setiap saat tetapi perlu adanya pemahaman dan peningkatan kemampuan berbicara khususnya di lingkungan intelektual. Faizah (2012: 2) menambahkan tingginya tuntutan perkembangan informasi turut memberikan sumbangan terhadap aktivitas berbicara sejalan dengan semakin pentingnya arus komunikasi di depan massa yang menuntut keprofesionalan pelaku komunikasi.

Pembelajaran berbicara di perguruan tinggi diarahkan untuk mahasiswa mengembangkan keterampilan berbicara di depan umum pada situasi formal maupun non formal yang lebih meluas sehingga memiliki pengalaman langsung yang dapat diaplikasikan guna pengembangan diri mahasiswa dalam berbicara yang diaplikasikan dengan bidang kesastraan pada situasi formal maupun nonformal. Oleh sebab itu, diperlukan bekal yang dapat direalisasikan mahasiswa saat bermasyarakat maupun di lingkungan kerja. Materi pembelajaran berbicara meliputi (1) konsep dasar dalam berbicara, (2) faktor-faktor yang mempengaruhi efektivitas berbicara, (3) analisis kesalahan-kesalahan seorang pembicara, (4) ragam berbicara di depan umum, dan (5) hakikat dan praktik sebagai pembawa acara, moderator, debat, wawancara, pidato, dan mendongeng.

c) Pengembangan Bahan Ajar

Bahan ajar adalah seperangkat sarana atau alat pembelajaran yang berisikan materi pembelajaran, metode, batasan-batasan, dan cara mengevaluasi yang didesain secara sistematis dan menarik dalam mencapai tujuan yang diharapkan, mencapai kompetensi atau sub kompetensi dengan segala kompleksitasnya (Widodo dan Jasmadi, 2008: 40). Pengembangan bahan ajar juga perlu memperhatikan hal-hal yang berkaitan sehingga tepat dilakukan dan digunakan. Selanjutnya, tujuan pengembangan bahan ajar meliputi 1) membantu proses pembelajaran yang disesuaikan dengan kurikulum, 2) menjadi pendukung dan pelengkap buku-buku teks lainnya, 3) mempermudah peserta didik dan pendidik dalam memiliki sumber buku utama dalam pembelajaran, dan 4) mempermudah pendidik dalam menyesuaikan buku yang digunakan dengan kondisi perguruan tinggi maupun peserta didik.

\section{d) Metode Student Facilitator And Explaining}

Model pembelajaran student facilitator and explaining dalam pelaksanaannya mempunyai kelebihan, yaitu: a. materi yang disampaikan lebih jelas dan konkret, b. dapat meningkatkan daya serap siswa karena pembelajaran dilakukan dengan demonstrasi, c. melatih siswa untuk menjadi guru karena siswa 
diberikan kesempatan untuk mengulangi penjelasan guru yang telah dia dengar, d. memacu motivasi siswa untuk menjadi yang terbaik dalam menjelaskan materi ajar, dan e. mengetahui kemampuan siswa dalam menyampaikan ide atau gagasan (Trianto, 2007:41). Oleh sebab itu, melalui pembelajaran teman sejawat diharapkan mampu menimbulkan motivasi dan meningkatkan kemampuan dalam proses pembelajaran mahasiswa sebab rasa canggung akan dapat diatasi.

\section{METODE PENELITIAN}

Penelitian ini dilakukan pada semester 3 Pendidikan Bahasa Indonesia di Universitas Peradaban dengan pertimbangan belum tersedianya bahan ajar Mata Kuliah Berbicara. Universitas tersebut beralamat di Jalan Raya Pagojengan KM.3, Paguyangan, Kabupaten Brebes, Jawa Tengah 52276. Prosedur pengembangan yang dilakukan meliputi: (a) perencanaan, (b) studi eksplorasi, dan (c) pengembangan bentuk awal produk. Pertama, perencanaan dilakukan dengan melakukan pengembangan dengan rincian penyusunan draf buku ajar, validasi ahli, dan uji lapangan terbatas. Selanjutnya, uji coba utama dengan melakukan pretest, pelaksanaan uji coba, observasi, dan post-test. Kedua, studi eksplorasi dilakukan melalui studi pusaka dan studi lapangan. Ketiga, pengembangan bentuk awal produk buku ajar Berbicara yang dilakukan dengan kolaborasi bersama review pakar dan pengguna.

\section{HASIL DAN PEMBAHASAN}

Pada bagian ini dideskripsikan temuan-temuan yang diperoleh dari tahap pelaksanan penelitian pengembangan yang telah dilakukan, yaitu: (1) tahap persiapan meliputi studi pustaka, eksplorasi, dan penyusunan draf awal, (2) tahap studi pengembangan meliputi expert judgement, uji coba awal dan perbaikan, uji coba luas dan perbaikan, uji coba luas dan perbaikan, dan (3) tahap eksperimen meliputi persiapan dan pelatihan, pelaksanaan eksperimen, analisis data, dan penyimpulan.

\section{Tahap Persiapan}

Pada tahap persiapan terdiri dari studi pustaka, studi eksplorasi, dan penyusunan draf awal yang diuraikan sebagai berikut.

\section{a) Studi Pustaka}

Pada Program Studi Pendidikan Bahasa Indonesia FKIP Universitas Peradaban terdapat dua Mata Kuliah Berbicara yakni pada semester 1 Berbicara 1 dan pada semester 3 Berbicara 2. Pada Berbicara 1, materi difokuskan terkait ruang lingkup berbicara serta praktik berbicara dalam membawakan acara dalam situasi resmi atau tidak resmi. Selanjutnya, pada Mata Kuliah Berbicara 2, materi yang diberikan pada mahasiswa berkaitan dengan pengulangan pemahaman ruang lingkup berbicara disertai penambahan praktik sebagai upaya pemberian pengalaman saat di lingkungan kerja. Tahun ajaran 2017/2018 merupakan angkatan pertama mahasiswa semester 3 PBSI FKIP Universitas Peradaban yang menempuh Mata Kuliah Berbicara 2. Oleh sebab itu, studi pustaka 
dilakukan dengan melacak bukubuku yang pernah diajar oleh dosen Mata Kuliah Berbicara 1.

Tanggapan informan dosen dan mahasiswa terhadap bahan ajar yang digunakan dalam mata kuliah Berbicara sebelumnya adalah buku milik Henry Guntur Tarigan yang berjudul "Berbicara Sebagai Suatu Keterampilan Berbahasa" yang diterbitkan oleh Angkasa tahun 2008. Selanjutnya, aspek-aspek yang digunakan sebagai bahan tanggapan pada tersebut meliputi (1) kelayakan isi materi, (2) penggunaan bahasa, (3) penyajian, dan (4) grafika. Pertama, kelayakan isi materi. Pengertian dan penjelasan tentang hakikat berbicara telah sesuai dengan materi yang disampaikan pada pembelajaran berbicara. Kekurangannya pada bagian isi adalah penulis belum menguraikan contoh yang jelas yang spesifik terkait contoh praktik dalam berbicara dalam situasi resmi atau tidak resmi.

Kedua, penggunaan bahasa. Penulis telah menerapkan penggunaan bahasa Indonesia yang baik dan benar. Selain itu, bahasa yang dipilih juga tidak menimbulkan persepsi ganda dan logis sehingga mudah dipahami. Ketiga, penyajian materi. Penulis belum melibatkan pembaca untuk ikut serta mengevaluasi pemahaman maupun kemampuan setelah membaca dan memepelajari teori yang disampaikan. Oleh sebab itu, diperlukan adanya bagian latihan maupun pemberian tugas pada setiap sub materi. Selain itu, faktor pemberian contoh gambar atau ilustrasi juga perlu dilakukan pada beberapa bagian untuk menimbulkan ketertarikan dan imajinasi saat mempelajari. Keempat, grafika.
Penggunaan bentuk tulisan, ukuran huruf, kertas, spasi, dan tata letak sudah lengkap. Bila pada materi ada penambahan contoh praktik berbicara melalui gambar, tabel, dan lain sebagainya akan menambah kelengkapan dari bagian ini.

Berdasarkan hasil wawancara dan observasi dengan dosen Mata Kuliah Berbicara I serta mahasiswa semester 3 PBSI FKIP Universitas Peradaban disimpulkan bahwa dibutuhkan bahan ajar Mata Kuliah Berbicara yang dilengkapi dengan contoh uraian pembelajaran, latihan maupun tugas. Beberapa buku yang digunakan oleh dosen masih menggunakan buku-buku yang mengambil bagian-bagian tertentu dalam tiap buku sehingga menyulitkan mahasiswa dalam mengikuti materi yang disampaikan. Oleh karena itu, diperlukan adanya pengembangan bahan ajar Mata Kuliah Berbicara yang disesuaikan pada perkembangan sekitar mahasiswa yang berpedoman pada kurikulum, siap digunakan pada kondisi tersedianya fasilitas yang minimal serta materi yang menarik bagi mahasiswa.

\section{b) Studi Eksplorasi}

Studi eksplorasi dilakukan observasi dan wawancara dengan beberapa mahasiswa disimpulkan bahwa kemampuan berbicara mahasiswa masih tergolong rendah. Jumlah mahasiswa PBSI semester 3 yang telah menempuh Mata Kuliah Berbicara I sebanyak 17 hanya 4 mahasiswa yang memperoleh nilai 75 s.d. 87 sedangkan lainnya memperoleh nilai di bawah 70 bahkan ada yang memperoleh nilai 55. Permasalahan yang terjadi diantaranya (1) mahasiswa masih 
mengalami kesulitan dalam menyusun naskah teks dalam berbicara, (2) mahasiswa melalaikan kesantunan nonverbal, mahasiswa belum terbiasa menggunakan bahasa maupun pengucapan yang baik dan benar sehingga masih sering menerapkan bahasa keseharian seperti biarin, anu, tidak' dan lain sebagainya, (4) minat terhadap berbicara masih rendah, dan (5) rasa tidak percaya diri yang belum dapat diatasi oleh mahasiswa.

\section{c) Penyusunan Draf Awal}

Penyusunan model awal mengacu pada standar kompetensi dan kompetensi dasar Mata Kuliah Berbicara yang disesuaikan dengan kurikulum. Format rancangan silabus memiliki struktur meliputi standar kompetensi, kompetensi dasar, materi pelajaran, kegiatan pembelajaran, indikator, penilaian, alokasi waktu, dan bahan pembelajaran. Selanjutnya, format model rancangan pembelajaran terdiri dari kompetensi dasar, materi pokok, indikator, pengalaman belajar, alokasi waktu, teknik penilaian, media, dan sumber pembelajaran. Desain produk awal bahan ajar memiliki 8 bagian berstruktur. Bagian 1 berisi tentang rasional pengembangan, landasan konseptual, landasan empiris, dan langkah-langkah pengembangan.

Bagian 2 berisi tentang pemahaman ruang lingkup berbicara. Bagian 3 berisi tentang langkahlangkah awal untuk meningkatkan minat meningkatkan kemampuan berbicara. Bagian 4 berisi tentang materi pidato. Bagian 5 berisi tentang materi MC. Bagian 6 berisi tentang materi penyiar radio. Bagian
7 berisi tentang moderator. Bagian 8 berisi tentang mendongeng. Bahan ajar Berbicara dilengkapi pula dengan RPS, silabus, dan evaluasi pembelajaran berbicara berbasis student facilitator and explaining dengan harapan pembelajaran dapat terlaksana lebih fokus dan sistematis. Indikator ketercapaian pembelajaran Mata Kuliah Berbicara meliputi ketercapaian dalam berpidato, MC, penyiar radio, moderator, dan mendongeng.

\section{Tahap Studi Pengembangan}

Pada tahap pengembangan terdiri dari beberapa langkah antara lain expert judgment, uji coba awal dan perbaikan, uji coba luas dan perbaikan, uji coba luas perbaikan, dan uji coba akhir dan perbaikan.

\section{a) Expert Judgment}

Setelah melaksanakan pengembangan desain produk awal menjadi bahan ajar Mata Kuliah Berbicara dilanjutkan dengan konsultasi untuk validasi dan revisi produk dengan pakar. Konsultasi terhadap produk awal yang akan diujicobakan, dilakukan dengan pakar untuk mendapat komentar dan saran serta persetujuan sehingga prototype yang berupa produk awal menjadi sebuah produk bahan ajar Mata Kuliah Berbicara. Tahapan awal expert judgment di awali dengan pemahaman kurikulum dan silabus yang akan digunakan sebagai bahan dalam penyusunan RPS. Selanjutnya, disesuaikan topik materi bahan ajar yang akan disusun dilanjutkan dengan validitas oleh pakar.

Berdasarkan hasil expert judgment diperoleh evaluasi terkait 
produk awal meliputi (1) perbaikan format RPS (Rencana Pembelajaran Semester), (2) perbaikan judul bahan ajar, (3) penambahan bagain1 dalam buku ajar terkait rasional pengembangan, landasan konseptual, landasan empiris, dan langkahlangkah pengembangan, dan (4) penambahan catatan-catatan simpulan dalam tiap bab materi dilanjutkan penambahan ilustrasi gambar/dokumentasi pada materi mc dan mendongeng. Pada bab mc ditambahkan bagaimana cara memegang mikrofon sedangkan pada bab mendongeng ditambahakan dokumentasi mendongeng dengan berbagai alat peraga yang diajarkan. Pada bab pidato ditambahkan beberapa contoh naskah pidato yang disesuaikan dengan beberapa kegiatan untuk mahasiswa. Silabus dan RPS yang dikonsultasikan pada expert judgment sudah dianggap baik atau sesuai dengan kurikulum dalam perguruan tinggi serta pembelajaran Mata Kuliah Berbicara.

\section{b) Uji Coba Awal dan Perbaikan}

Setelah dilakukan revisi desain bahan ajar berdasarkan tanggapan dan saran perbaikan pakar dilanjutkan dengan uji coba awal. Hal ini dilakukan untuk tujuan mendapat masukan dari pengguna bahan ajar tentang desain awal bahan ajar yang efektif yang uji cobanya akan dilakukan pada semester 3 PBSI FKIP Universitas Peradaban. Uji coba awal dilakukan dengan menerapkan bahan ajar Mata Kuliah Berbicara dengan kompetensi MC dalam situasi resmi maupun tidak resmi. Sebelum uji coba awal, dilaksanakan pretes dan setelah uji coba dilaksanakan pretes pada masing-masing kompetensi. Uji kompetensi tersebut bersifat praktik dan susunan acara yang telah disiapkan oleh dosen.

Pembelajaran dilakukan dengan penyampaian materi terkait hakikat berbicara. Selanjutnya, mahasiswa dibagi dalam kelompok dan diajak bersama-sama untuk menyimak tayangan video yang ditampilkan lalu mengidentifikasi video tersebut berdasarkan penampilan pembawa acara, situasi acara, kesalahankesalahan serta kesantunan yang telah dilakukan pembawa acara. Hasil identifikasi tiap kelompok dipresentasikan sehingga disimpulkan beberapa temuan dan hasil perbaikan melalui kegiatan tanya jawab antara tiap kelompok dan dosen.

Berdasarkan hasil uji coba awal dan perbaikan disimpulkan bahwa kemampuan berbicara masih belum sesuai kriteria. Kendala-kendala yang dialami oleh mahasiswa diantaranya disebabkan karena belum terbiasanya mahasiswa dalam menggunakan bahasa Indonesia yang baik dan benar, merasa bingung ingin berkata apa, belum terbiasa tampil di depan umum sehingga tindakan seperti menggaruk kepala, kaki digerak-gerakan, seluruh tubuh terasa kaku, dan lain sebagainya. Oleh karena itu, diperlukan materimateri yang dekat dengan lingkungan mahasiswa. Hasil dari wawancara dengan perwakilan mahasiswa, praktik berbicara yang diharapkan meliputi pidato, pembawa acara, moderator, dan kemampuan yang dapat mendukung tambahan di lingkungan kerja seperti penyiar radio dan mendongeng.

Selanjutnya, disimpulkan pula untuk pembelajaran dapat lebih efektif diperlukannya peran teman sejawat dalam membantu teman 
lainnya sebagai teman diskusi dan juga pembelajar. Hasil observasi diketahui mahasiswa yang memiliki kemampuan berbicara rendah hanya menunjukkan tindakan berdiam diri maupun terkadang bertanya dengan teman sebelahnya. Diharapkan saat belajar bersama dengan temannya tidak ada rasa canggung dalam bertanya dan meningkatkan rasa motivasi untuk memperbaiki diri dalam pembelajaran berbicara secara berkelanjutan. Oleh sebab itu, disimpulkan pada uji coba luas akan diterapkan metode student facilitator and explaining.

\section{c) Uji Coba Luas dan Perbaikan}

Setelah dilakukan uji coba primer dalam skala kecil dilanjutkan dengan melakukan uji coba produk yang telah diperbaiki pada subjek yang lebih luas. Pada uji luas ini tidak mengalami kendala yang signifikan karena semua prosedur pelaksanaan dilaksanakan secara terprogram dan terencana serta pengajaran mampu diterima dan diserap oleh mahasiswa. Hasil uji coba ini digunakan untuk menentukan signifikasi peningkatan kompetensi berbicara mahasiswa. Perbaikan produk yang mengacu pada uji luas adalah mahasiswa masih mengalami kesulitan saat diminta untuk tampil membawakan acara dengan berpasangan. Oleh karena itu, perbaikan berikutnya yang dilakukan adalah menambahkan contoh naskah pembawa acara dengan berpasangan.

Pada pertemuan sebelumnya mahasiswa diminta untuk memahami, menyusun, dan menampilkan kemampuan berbicara secara mandiri akan dilakukan perubahan penerapan dengan metode student facilitator and explaining.
Langkah awal yang dilakukan adalah dosen mengulas kembali penjelasan tentang materi ruang lingup berbicara dan persiapan-persiapan dalam materi berbicara sebagai mc, pidato, dan moderator. Selanjutnya, mahasiswa dibagi menjadi tiap kelompok. Satu kelompok berisi 2 orang. Pembagian kelompok dibuat menjadi dua, kelompok student facilitator and explaining yang telah disiapkan oleh dosen dengan kriteria pemahaman dan kemampuan berbicara sesuai dengan tuntas kriteria yang telah ditentukan. Kelompok tersebut akan memiliki tugas untuk membantu anggotanya dalam meningkatkan pemahaman dan kemampuan berbicara. Kelompok anggota dilakukan secara undian.

Hasil penerapan metode student facilitator and explaining diketahui terjadi peningkatan minat dan motivasi prestasi belajar mahasiswa dalam kemampuan berbicara. Teman sejawat memiliki pengaruh dalam membantu peran dosen sebagai rekan pembelajar sebab belajar dengan teman sendiri akan leluasa atau tidak malu untuk bertanya bila ada yang tidak dipahami dan dalam berkomunikasi tidak ada rasa canggung. Oleh karena itu, disimpulkan apabila metode student facilitator and explaining efektif diterapkan dalam meningkatkan kemampuan berbicara mahasiswa PBSI FKIP Universitas Peradaban dalam Mata Kuliah Berbicara.

\section{d) Uji Coba Akhir dan Perbaikan}

Uji coba bahan ajar dilakukan pada materi berikutnya yakni materi penyiar radio dan mendongeng dengan bekerja sama dengan ahli pakar. terkait konsultasi mengenai 
materi tersebut yang ada dalam bahan ajar, pengajaran, kendala yang dialami serta berketerimaan bahan ajar tersebut pada mahasiswa secara menyeluruh. Dalam uji coba akhir tersebut dilakukan secara random sampling terkait materi yang akan disampaikan dengan materi penyiar radio dan mendongeng. Pada materi penyiar radio terdapat kelemahan dan kendala yang terjadi disebabkan dari keterbatasan piranti penyiar radio yang dimiliki sehingga dosen hanya menyampaikan penjelasan bentuk dan fungsi piranti melalui gambar sehingga belum dapat melihat wujud dan mempraktikan secara langsung.

Disimpulkan bahwa materi penyiar radio menjadi bahan evaluasi untuk dapat dilakukan tindak lanjut. Dapat dilakukan dengan melalui kunjungan langsung ke lokasi siaran di daerah Bumiayu ataupun materi ini menjadi alternatif pilihan. Di sisi lain dari hasil praktik, mahasiswa menampilkan layaknya penyiar radio terutama dengan acara yang dibawakan kategori penyimak remaja. Oleh karena itu, khusus materi penyiar radio perlu ada tindak lanjut disebabkan keterbatas fasilitas pendukung

\section{Tahap Eksperimen}

Pada tahap eksperimen terdiri dari (a) persiapan dan pelatihan, (b) persiapan eksperimen, dan (c) analisis data dan penyimpulan yang akan dijelaskan lebih lanjut di bawah ini.

\section{a) Persiapan dan Pelatihan}

Pengukuran awal pada mahasiswa diberikan pretes yang sama yakni berlaku sebagai pembawa acara. Oleh sebab itu, diperlukan sebuah inovasi agar penampilan mahasiswa dapat maksimal dengan menerapkan metode student facilitator and explaining yakni belajar dengan teman sejawat. Penerapan metode tersebut dibagi menjadi kelompok mahasiswa kontrol dan kelompok mahasiswa eksperimen. Kelompok eksperimen dikelompokkan dari hasil observasi dan hasil prestasi mahasiswa yang sesuai dengan kriteria ketuntasan dari kemampuan berbicara sebagai pembawa acara. Selanjutnya, kelompok ini diberikan pembekalan pemantapan materi di luar jam perkuliahan. Kelompok ini yang akan berperan dalam menerapkan metode student facilitator and explaining dan membantu kelompok kontrol dalam mempelajari dan meningkatkan kemampuan berbicara.

b) Pelaksanaan Eksperimen

Pembelajaran Mata Kuliah Berbicara dinyatakan efektif apabila pembelajaran menggunakan perangkat yang memberikan hasil sesuai indikator meliputi (1) ketuntasan belajar klasikal mahasiswa, (2) hasil belajar siswa meningkat, (3) ada pengaruh positif keaktifan mahasiswa terhadap hasil belajar, dan (4) perangkat pembelajaran yang dikembangkan telah dinyatakan valid dan praktis berdasarkan validasi ahli/pakar. Tahap eksperimen dilakukan dengan lima kompetensi, yaitu: berpidato, MC, penyiar radio, moderator, dan mendongeng dengan melakukan tes uji pada tiap akhir pertemuan.

Tahap berikutnya, hasilnya dinilai dan dibahas. Selanjutnya, setelah eksperimen pembelajaran selesai dilakukan tes praktik berbicara pada masing-masing kompetensi. Hasil tes dianalisis menggunakan uji 
ketuntasan belajar sebesar 70. Tahap ini dilihat dari hasil pengamatan dan penilaian terhadap aktivitas mahasiswa selama pembelajaran. Pengamatan dilakukan terhadap aspek-aspek kecepatan pemahaman siswa terhadap pembelajaran, kreativitas mahasiswa, dan hasil belajar. Berikut ini rubrik penilaian yang digunakan dalam perkuliahan berbicara.

c) Analisis Data dan Penyimpulan

$\begin{array}{lcr}\text { Indikator untuk menilai } \\ \text { keefektifan metode } & \text { student } \\ \text { facilitator and } & \text { explaining } & \text { meliputi } \\ \text { (1) kecepatan pemahaman } & \text { terhadap }\end{array}$

pelajaran, (2) perubahan kreativitas, dan (3) hasil belajar dengan penilaian (4) sangat cepat, (3) cepat, (2) agak cepat atau (1) lambat untuk penilaian kecepatan pemahaman terhadap pelajaran. Selanjutnya, nilai (4) sangat tinggi, (3) tinggi, (2) agak tinggi atau (1) rendah untuk penilaian perubahan kreativitas dan nilai (4) sangat tinggi, (3) tinggi, (2) agak tinggi atau (1) rendah guna menilai indikator hasil belajar. Berdasarkan hasil observasi dan uji coba diketahui perbandingan kinerja dengan metode konvensional dengan metode student facilitator and explaining melalui diagram di bawah ini.

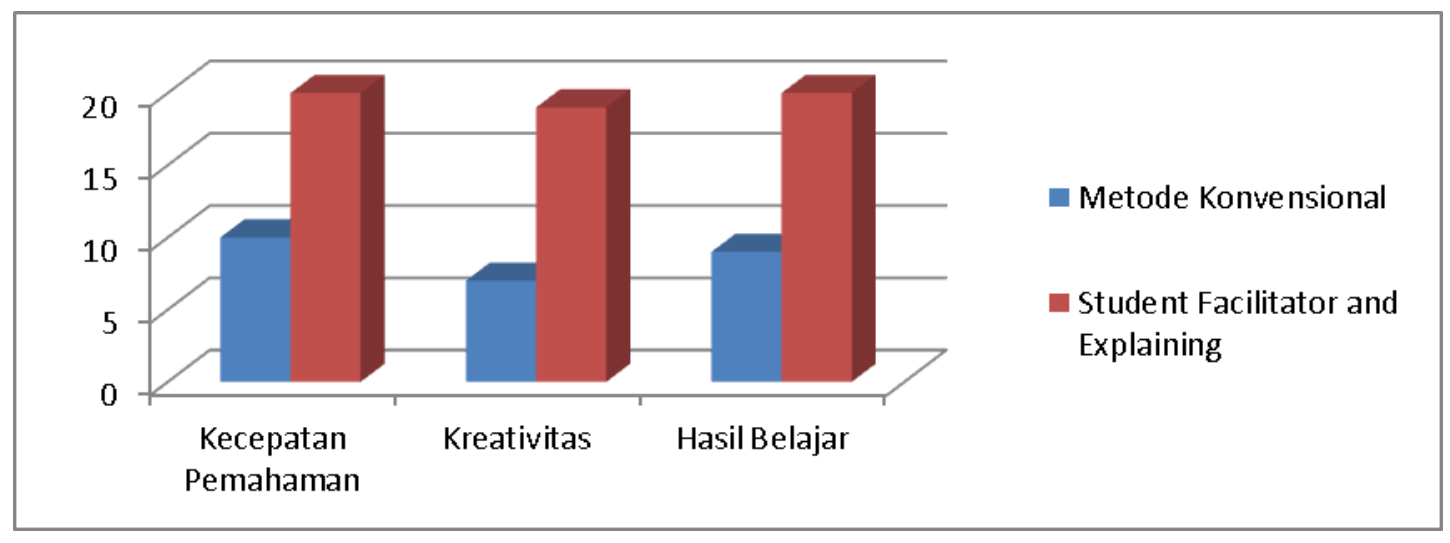

Gambar 1 Perbandingan Metode Konvensional dengan Metode Student Facilitator and Explaining

Berdasarkan gambar di atas, dapat diketahui bila pembelajaran dengan metode student facilitator and explaining meningkatkan kemampuan berbicara mahasiswa dengan indikator kecepatan pemahaman, kreativitas, dan hasil belajar yang lebih tinggi dibandingkan saat menerapkan metode konvensional. Kecepatan pemahaman saat menggunakan metode konvensional sebanyak 10 mahasiswa meningkat menjadi 20 mahasiswa saat diterapkan metode student facilitator and explaining. Indikator kreativitas dari 7 mahasiswa meningkat menjadi 19 mahasiswa dan hasil belajar dengan metode konvensional sebanyak 9 mahasiswa meningkat sebanyak 20 mahasiswa setelah diterapkan metode student facilitator and explaining.

Selanjutnya, uji kelayakan bahan ajar Mata Kuliah Berbicara dengan metode student facilitator and explaining meliputi 4 komponen, yakni: 1) kelayakan isi materi, 2) 
kebahasaan, 3) penyajian, dan 4) grafika. Instrumen kelayakan bahan ajar diisi oleh 24 responden yang hadir dalam pengembangan bahan ajar terdiri dari 23 mahasiswa dan 1 dosen pengampu Mata Kuliah Berbicara 1. Pernyataan yang diajukan berjumlah 10 pertanyaan. Berikut ini tabel pertanyaan angket uji kelayakan bahan ajar berbicara dengan metode student facilitator and explaining.

Hasil pengisian dari angket diketahui bahwa 22 orang yang menyatakan sangat setuju dan 2 orang menyatakan setuju terkait wacana dan materi bahan ajar berbicara menggunakan bahasa yang jelas dan mudah dipahami serta menggunakan bahasa Indonesia yang baik dan benar. Terdapat, 24 sangat setuju orang yang menyatakan bila wacana dan materi bahan ajar berbicara tidak bermakna ambigu dan tujuan pembelajaran diuraikan secara tertulis. Tahapan pembelajaran dilakukan berdasarkan urutan tingkat kesulitan dinyatakan oleh 22 orang yang menyatakan sangat setuju dan 2 orang menyatakan setuju. Selain itu, 24 orang menyatakan sangat setuju bahwa penyampaian bahan ajar disesuaikan dengan kebutuhan mahasiswa, universitas, dan masyarakat.

Selanjutnya, kegiatan pembelajaran telah mengarahkan mahasiswa dalam kegiatan berbicara secara kongkret dan penyajian materi, soal, latihan, dan tugas sesuai dengan indikator pembelajaran.dinyatakan sangat setuju oleh 24 orang. Terdapat 21 orang yang menyatakan sangat tidak setuju dan 3 orang menyatakan tidak setuju bila penyajian materi kurang menstimulasi mahasiswa untuk berpikir dan bernalar. Terdapat 20 orang yang menyatakan sangat tidak setuju dan 4 orang menyatakan tidak setuju dalam penggunaan ilustrasi gambar tidak sesuai dengan materi bahan ajar berbicara. Selain itu, 24 orang yang menyatakan bahwa desain tampilan bahan ajar menarik minat belajar mahasiswa.

\section{SIMPULAN}

Berdasarkan hasil pembahasan di atas, terdapat tiga simpulan. Pertama, kebutuhan bahan ajar Berbicara perlu memperhatikan a) pemilihan bahasa, b) topik pembelajaran disesuaikan dengan permasalahan yang dekat dengan mahasiswa, c) terdapat latihan dan tugas dalam tiap materi yang mudah dipahami, dan d) bahan ajar siap digunakan sesuai dengan kondisi universitas. Kedua, mengembangkan prototype menjadi bahan ajar berbicara di Universitas Peradaban. Terdapat lima kompetensi yang diajarkan meliputi berpidato, MC, penyiar radio, moderator, dan mendongeng. Kompetensi penyiar radio perlu dilakukan evaluasi dan tindak lanjut sebab minimalnya fasilitas yang tersedia tetapi hasil motivasi, kuesioner, dan prestasi belajar menunjukkan bila kompetensi tersebut dibutuhkan bagi mahasiswa dalam pengembangan kemampuan berbicara. Ketiga, hasil uji keefektifan menunjukkan bahan ajar berbicara dengan metode student facilitator and explaining dinyatakan baik. Pembelajaran dengan teman sejawat dapat membantu keberhasilan mahasiswa dalam belajar meningkatkan kemampuan berbicara. 


\section{DAFTAR PUSTAKA}

Chaer, Abdul. 2010. Kesantunan Berbahasa. Jakarta: Rineka Cipta.

Faizah, Umi. 2012. Peran Mata Kuliah Retorika dalam Pembinaan Budi Pekerti dan Moral Bangsa (Studi Kasus Mahasiswa Pendidikan Bahasa dan Sastra Indonesia). Surya Bahtera,1 (1): 1-12.

Rahardi, R. K.. 2007. Seni Memilih Kata Peranti dan Strategi Komunikasi Profesional Efektif dalam Wahana Bahasa Indonesia. Yogyakarta: Yayasan Pustaka Nusatama.

Sulistyo, Edy Tri. 2013. Pragmatik Suatu Kajian Awal. Surakarta: UNS Press.

Trianto. 2007. Model Pembelajaran Terpadu dalam Teori dan Praktek. Jakarta: Kencana.

Widodo, C. dan Jasmadi. 2008. Buku Panduan Menyusun Bahan Ajar. Jakarta: PT Elex Media Komputindo. 